\title{
PRELIMINARY WIND ANALYSIS REGARDING DIFFERENT SPEED RANGES IN THE CITY OF LA PLATA, ARGENTINA
}

\author{
GUSTAVO RATTO ${ }^{1,2}$, ANDRÉS NICO ${ }^{3,4}$ \\ ${ }^{1}$ Centro de Investigaciones Ópticas (CIOp), La Plata, Argentina \\ ${ }^{2}$ Nacional de La Plata Facultad de Ingeniería, Universidad, La Plata, Argentina \\ ${ }^{3}$ Centro Agrario El Chaparillo, Junta de Comunidades de Castilla La Mancha. Ciudad Real. Spain \\ ${ }^{4}$ Fundación Parque Científico y Tecnológico de Albacete, Programa INCRECYT, Albacete, Spain \\ gustavratto@gmail.com,
}

Received February 2011 - Accepted December 2011

\begin{abstract}
La Plata city (approximately 800000 inhabitants) has intense traffic and industrial activity; nevertheless, the city has no governmental air monitoring network for air pollutants and winds have been scarcely studied. Wind observations provided here (covering 1998- 2007) belong to a weather station that was contrasted against the unique governmental site in the city area (the Airport). The present preliminary study analyses wind direction frequencies according to wind speeds and emphasizes wind patters within the first hour after calm occurrences.

Results show that independently of the wind speed, wind direction frequency roses are in general similar to each other. Low wind speeds may occur most of the time (on average $58.2 \%$ ) and together with calm occurrences (on average 17.1\% ) constitute an important factor for the accumulation of air pollutants. The proposed "outgoing of calm" wind direction frequency roses were found to be appropriate to gain knowledge in the structure of winds that transport pollutants towards exposed population after calm occurrences. Long term systematic meteorological fieldworks should be encouraged in the future so as to provide better tools for environmental modeling.
\end{abstract}

Keywords: calm analysis, La Plata, wind analysis, wind roses

RESUMO: ANÁLISE PRELIMINAR DO VENTO SEGUNDO DIFERENTES FAIXAS DE VELOCIDADES NA CIDADE DE LA PLATA, ARGENTINA

A cidade de La Plata (aproximadamente 800.000 habitantes) tem tráfego e atividade industrial intensos. Contudo, não tem uma rede oficial de monitoramento para os contaminantes do ar e os ventos têm sido pouco estudados. As observações dos ventos aqui apresentadas (desde 1998 até 2007) correspondem a uma estação meteorológica que foi comparada com o único sitio oficial de registros de ventos na área urbana (o Aeroporto). O presente estudo preliminar analisa as frequências das direções do vento, segundo as suas velocidades, e coloca ênfase nos padrões de vento na primeira hora após as ocorrências calmarias.

Os resultados mostram que as rosas de frequências de direções de ventos são em geral similares entre elas independentemente das velocidades. Velocidades baixas de ventos são factíveis de acontecer na maior parte do tempo (na média 58,2\%), e, junto com as ocorrências de calmarias (na média 17,1\%), constitui um fator importante para acumulação dos contaminantes. As rosas de frequência de direções de ventos propostas, nomeadas "saída de calmarias", resultaram ser apropriadas para o conhecimento da estrutura dos ventos que transportam os contaminantes acumulados em direção à população exposta, após períodos de calmaria. Na meteorologia deveriam se incentivados os trabalhos de campo sistemáticos, de longo prazo, de forma a prover melhores ferramentas para a modelagem de meio ambiente.

Palavras Chaves: análise de calmaria, La Plata, análise de vento, rosa dos ventos. 


\section{INTRODUCTION}

The city of La Plata is considered, along with its neighboring areas (approximately 800000 inhabitants), one of the six most potentially hazardous cities in Argentina regarding air pollution (Petcheneshky et al., 1998). An industrial complex (see the rectangle in Figure 1) containing the country's main oil refinery (total crude oil processing capacity of 32000 $\mathrm{m}^{3} /$ day), petrochemical plants, steel processing plants and a shipyard along with heavy traffic activity (approximately 300 000 vehicles) (Whichmann et al., 2009) are the main sources of anthropogenic airborne pollutants. In addition, a new thermal power station (with a capacity of $560 \mathrm{MW}$ ) constructed in the vicinity areas of the industrial complex is due to be operating at the beginning of 2012. Besides the local burden of regional pollutants contributors, such as those belonging to biomass burning transported by low- level jets (Ulke et al., 2007; Ulke, 2009) should be taken into account in future studies. A recent study (Cataldi et al., 2010) points out the importance that regional anomalies (such as El Niño) may have in local atmospheric circulation patterns.

Although the great need of a systematic air pollution assessment, the city has no governmental monitoring network. Several works evaluate different aspects of air pollution in the

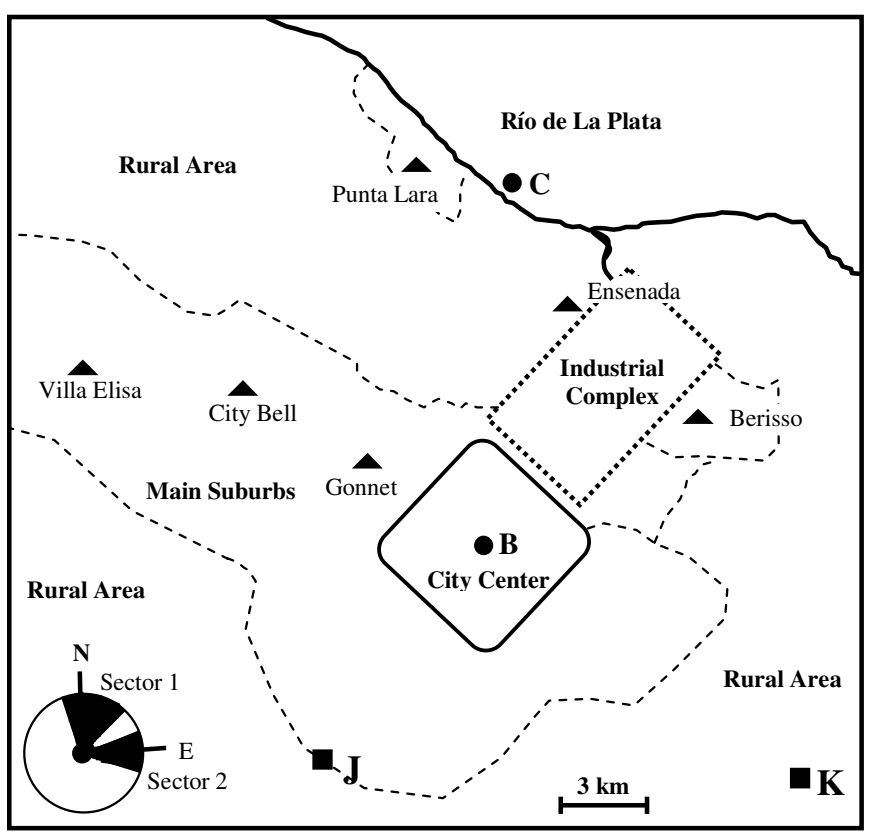

Figure 1 - Map covering parts of La Plata City and surroundings. Measurement points are indicated with a bolded square. Point B: city center. Point C: river bank. The rectangle indicates the area with high industrial activity. Point J: Agrometeorological Station (National University of La Plata). Point K: La Plata Airport. Bolded triangles indicate suburb centers. area (Colombo et al., 1999; Rosato et al., 2001; Ronco et al., 2001; Massolo et al., 2002; Rehwagen et al., 2005; Nitiu, 2006, Massolo et al., 2010) but winds have been scarcely studied. In previous reports (Ratto et al., 2006, Ratto et al., 2009, Ratto et al., 2010a) the need of knowing wind patterns was pointed out in order to provide basis to air pollution modeling. Also some aspects of the boundary layer meteorology, such as the characterization of atmospheric stabilities and mixing depth (Mazzeo et al., 1971) and turbulence studies (Marañon Di Leo et al., 2004) result scarce and incomplete up to date and should be encouraged together with a wind profile analysis in order to provide basic tools to be applied in environmental modeling.

This article is intended as a preliminary work. Its purpose is to analyze the behavior of frequency wind roses regarding different speed ranges in order to gain knowledge of wind structure. Moreover wind patterns after calms are analyzed, taking into account that pollutants tend to accumulate within the areas neighboring sources during calm events (Alvarez Escudero et al., 2007). The first winds after the calm would transport air masses with high charge of pollutants. Computing the first wind direction that appears after a calm and accumulating this count for a given period allows the building up of a wind rose named "outgoing of calms wind rose" - OOC wind rose hereafter. Seasonal $O O C$ wind roses are presented and their relationship with the averaged wind roses for different speed intervals are analyzed. As a consequence, wind directions relevant for the transport of air pollutant towards population exposed namely Sector 1 (NNW-NE) and Sector 2 (ENE- ESE) - see the bottom left corner of Figure 1- are discussed.

Overall comparisons between pairs of wind roses were carried out by applying the sum of the absolute values for the differences $(S A D)$ between frequencies. This metric was used as a dissimilarity criterion between wind roses but also provided a magnitude for the "error" of predicting outgoing of calms wind roses with the use of complete range wind roses. Measurements involved correspond to one monitoring site located in a semirural area (see Point $\mathrm{J}$ in Figure 1) that was in operation during 10 years. The observed data were seasonally grouped and compared to those of the La Plata Airport (see Point K in Figure 1) taken as reference.

\section{MATERIALS AND METHODS}

\subsection{Area description and data characteristics}

The city of La Plata is one of the most industrialized and populated cities within the La Plata River basin (3 200000 $\mathrm{km}^{2}$ ) in central- eastern South America. The city is located close to the coast of the La Plata River $\left(35^{\circ} \mathrm{S} 58^{\circ} \mathrm{W}\right)$ around $15 \mathrm{~m}$ above the sea level. Climate is temperate humid with an annual 
average temperature of $16^{\circ} \mathrm{C}$ and a medium annual rainfall of ca. $1000 \mathrm{~mm}$ (Negrin et al., 2007).

In the La Plata River region a considerable surface temperature contrast between water and land takes place setting the stage for the development of a low- level circulation with sea- land breeze characteristics (Berri et al., 2010). This circulation makes the wind blows from water to land during the day (i.e. sea- breeze) and from land to water during the night. Since this phenomena occurs in a flat terrain there are no other topographical effects that influence the low- level local circulation (Sraibman and Berri, 2009). This phenomenon was evidenced during a short campaign in La Plata city when wind direction frequency roses at Point $\mathrm{J}$ were compared with observations at a weather station located close to the industrial complex (Ratto et al., 2010b).

The unique study found in the area of La Plata regarding atmospheric stability analyses (Mazzeo et al., 1971) covered the period 1957-1966. It was carried out near the industrial complex and involved day- time hours. This study was based on Turner's classification where class A refers to an extremely unstable atmosphere, class B to unstable, class $\mathrm{C}$ to slightly unstable, class D to neutral, class $\mathrm{E}$ to slightly stable, class $\mathrm{F}$ stable and class $\mathrm{G}$ extremely stable. An overall view of stability classes on annual basis determined that class $\mathrm{D}$ was prevailing ( $49 \%$ of the time) followed by class E (20.8\%) and class C $(17.4 \%)$. The same study shows that the average mixing height values (measured during 1965-1968) for winter was about 700 $\mathrm{m}$ while for summer was about $1700 \mathrm{~m}$.

Monitoring site Point J (see Figure 1) is located in a semi- rural area around $18 \mathrm{~km}$ far from the river bank (labeled as $\mathrm{C}$ ) and around $9 \mathrm{~km}$ far from La Plata Airport. Data belonging to Point J - Agrometeorological Station- National University of La Plata- cover the period 1998- 2007 and were obtained with a GroWeather ${ }^{\circledR}$ Industrial. (Davis Instruments Corp, San Francisco, US) meteorological station. Wind directions were obtained every $22.5^{\circ}$ with an accuracy of $\pm 7^{\circ}$ of the read out. The detection limit and resolution for wind velocities were 1.6 $\mathrm{km} \mathrm{h}^{-1}$ and the accuracy $\pm 5 \%$ of the read out. This station measured at $5 \mathrm{~m}$ above the ground and provided 16- direction wind roses. The data spanning from summer 1998 to spring 2007 was provided in hourly averages. Winter 2000 had insufficient data and was disregarded (no method of gap filling was applied). Nevertheless, this loss represented just $10 \%$ of the missing data within the complete set for winters. The rest of the missing data for winters and the rest of the seasons were distributed randomly throughout the 10 years. The completeness of data for winters was of $88.3 \%$; the completeness of the data for all the seasons was on average $93.4 \%$. Previous to analyze how the observed seasonal frequency wind roses depend on wind speed, the wind speed structure was studied. As wind speeds provided by the weather station at Point $\mathbf{J}$ were given in discrete intervals of $1.6 \mathrm{~km} \mathrm{~h}^{-1}$ the frequency for each of the discrete values was accumulated.

The reference site (Point $\mathrm{K}$ ) is a weather station that belongs to the National Meteorological Service; it is located in a rural area and measures at 10 meters above the ground. The data set consisted of monthly averages for the decade 19912000. This decade was selected because it was the closest one available to the observed data. Frequencies and speeds were given for 8 directions wind roses.

\subsection{Statistical analysis}

In order to make comparable 16 directions wind roses (as those observed for Point $\mathrm{J}$ ) with 8 directions wind roses (those belonging to the reference site Point $\mathrm{K}$ ) a classical approach was applied (Conrad and Pollak, 1950). This approach takes the 16 directions wind roses, keeps unvaried the main eight directions and assigns half of the frequencies of the secondary directions to each one of the adjacent respective principal directions. With this method the wind roses of Figure 2 were estimated.

The well known "sum for the absolute values of the differences" - $S A D$ - is a metric that measures differences between vectors by addressing the "distance" between them. As the Euclidean distance, SAD is often employed to estimate similarity. It is indeed a dissimilarity measure because as far as it grows the patterns involved are considered more different.

$$
S A D=S A D_{x, y}=\sum_{i=1}^{n}\left|x_{i}-y_{i}\right|
$$

where $\mathrm{i}$ is the dimension (direction) of the pattern (wind rose) involved ( $\mathrm{n}$ is 8 or 16), $x_{i}$ the frequency of the pattern (wind rose) $\mathrm{X}$ in the direction $\mathrm{i}$ and $y_{i}$ the frequency of the pattern (wind rose) $\mathrm{Y}$ in the direction $\mathrm{i}$.

The first direction after the calm was counted in order to build the $O O C$ wind roses. Seasonal frequency $O O C$ wind roses were then built for the whole period under study.

\section{RESULTS}

Reduced seasonal wind roses observed at Point J show, at first sight, similar patterns to those corresponding to the reference site (Point K) for all seasons (Figure 2). Single absolute differences per direction between these wind roses were in all cases below $5.5 \%$. The similarity between sites involving wind frequencies is globally confirmed by obtained $S A D$ values (Table 1). Seasonal averaged wind speeds at points $J$ and $K$ together with averaged calms are shown in Table 2. Observed wind speed average at Point $\mathrm{J}$ is $6.6 \mathrm{~km} \mathrm{~h}^{-1}$ while at Point $\mathrm{K} 18.9 \mathrm{~km} \mathrm{~h}^{-1}$. Calm average at Point $\mathrm{J}$ is $17.1 \%$ while at Point $\mathrm{K}$ is $24.2 \%$. 


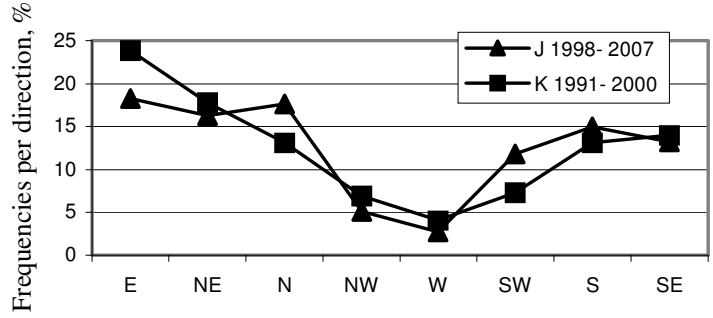

a)

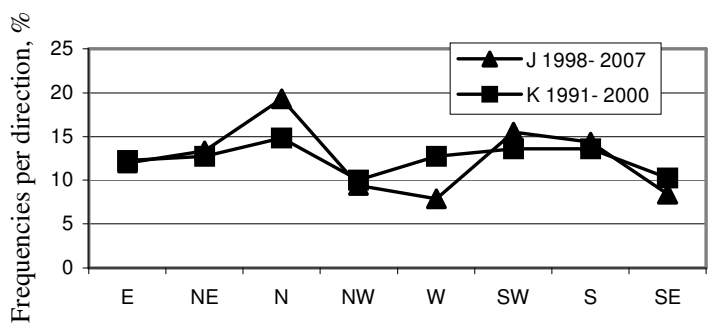

c)

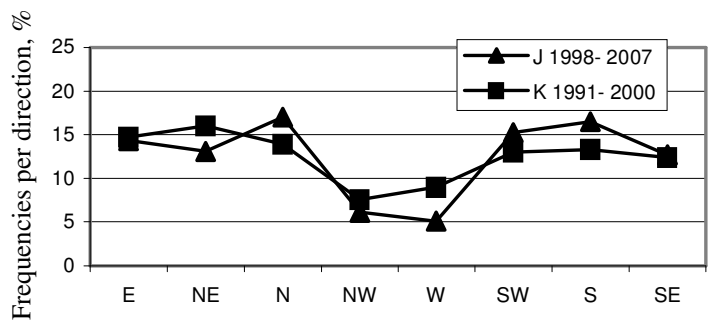

b)

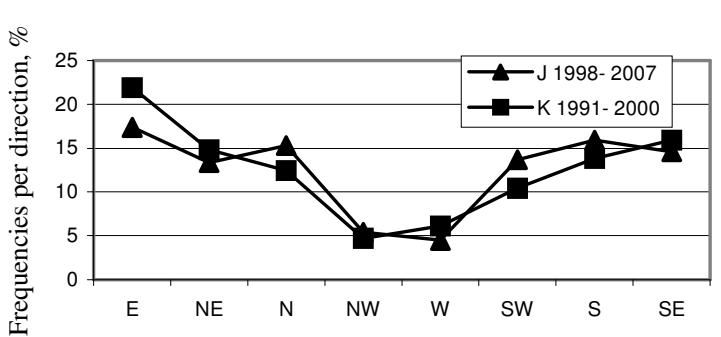

d)

Figure 2 - Total frequency percentual wind roses at Point J and K. Seasonal wind roses belonging to Point J have been reduced from 16 to 8 directions (Section 2.2) for the purpose of comparison with those at Point K (reference site). a) summer b) autumn c) winter and d) spring.

Table 1 - Seasonal $\mathrm{SAD}^{\mathrm{a}}$ values for the wind roses of Figure 2.

\begin{tabular}{|l|c|c|c|c|}
\hline & Summer & Autumn & Winter & Spring \\
\hline SAD & 21.8 & 17.5 & 15.5 & 17.9 \\
\hline
\end{tabular}

${ }^{\text {a }}$ Each SAD is computed taking into account the corresponding wind rose observed in points $\mathrm{J}$ and $\mathrm{K}$

Frequencies corresponding to contiguous wind speeds for the data observed at Point $\mathrm{J}$ are shown in Figure 3. Up to $9.7 \mathrm{~km} \mathrm{~h}^{-1}$ differences between frequencies of contiguous wind speeds are for all the seasons below $3.1 \%$. For wind speeds above $11.3 \mathrm{~km} \mathrm{~h}^{-1}$ these differences are larger but occurrences are rarer. These two characteristics suggest that contiguous wind speeds can be grouped into ranges; this step allows simplifying the subsequent analysis. Then, 4 speed ranges were built: 1.63.2 ; 4.8- 6.4; 8.0- 9.6 and $11.3-30.6 \mathrm{~km} \mathrm{~h}^{-1}$, also the complete range i.e. 1.6- $30.6 \mathrm{~km} \mathrm{~h}^{-1}$ is considered (Table 3, Figure 4).

Figure 5 shows seasonal $O O C$ wind roses together with the corresponding complete range wind roses. Considering single directions the main differences are: $5.4 \%$ for $\mathrm{N}$ and 2.9 $\%$ for NNE in Summer, 3.2 \% for N and 1.7\% for S in Autumn,
$6.7 \%$ for $\mathrm{N}$ and $4.1 \%$ for SSW in Winter and $6.2 \%$ for SW and $6.1 \%$ for NNE in Spring. As a whole, major individual differences are all below 7\%.

Estimated $S A D$ between seasonal wind roses of Figure 4 and their corresponding $O O C$ wind roses of Figure 5 (dash line) are shown in Table 4.

In order to compare frequencies of sectors 1 and 2 corresponding to the complete range wind roses to those corresponding to the $O O C$ wind roses Table 5 was built.

The ratio between starting wind speeds for the first hour after a calm involving complete range wind roses and $O O C$ wind roses are shown in Table 6.

\section{DISCUSSION}

The representativeness of meteorological data are userdependent (Wieringa, 1996). Wind observations at airportsmainly devoted to help with plane traffic (Wieringa, 1980)- are not very appropriate for air pollution considerations (Holzworth, 1967). Nevertheless, due to scarcity of meteorological data in the

Table 2 - Observed and reference seasonal averaged wind speeds and calms

\begin{tabular}{|l|c|c|c|c|c|c|c|c|}
\hline & \multicolumn{4}{|c|}{ Point J } & \multicolumn{4}{c|}{ Point K } \\
\hline & Summer & Autumn & Winter & Spring & Summer & Autumn & Winter & Spring \\
\hline AWS $^{\mathrm{a}}\left(\mathrm{km} \mathrm{h}^{-1}\right)$ & 6.9 & 6.4 & 6.7 & 6.2 & 19.2 & 17.7 & 18.5 & 20.1 \\
\hline Calms $^{\mathrm{b}}(\%)$ & 14.4 & 25.1 & 16.3 & 12.7 & 19.0 & 29.3 & 27.8 & 20.6 \\
\hline
\end{tabular}

${ }^{a}$ Average wind speed

${ }^{\mathrm{b}}$ Percent of time with winds below $1.6 \mathrm{~km} \mathrm{~h}-1$ respect to the total of occurrences 


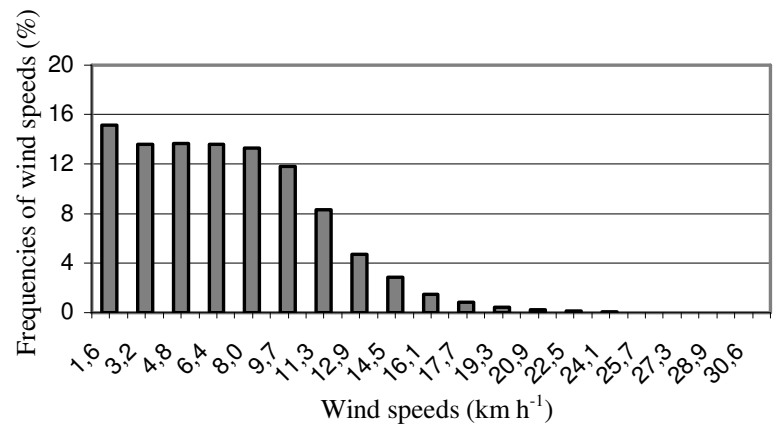

a)

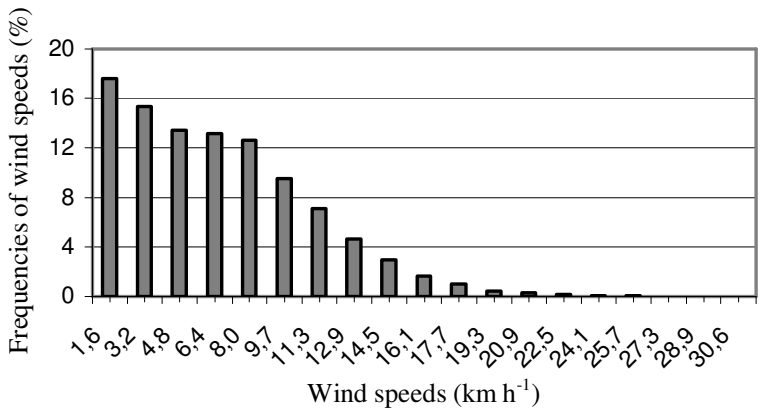

c)

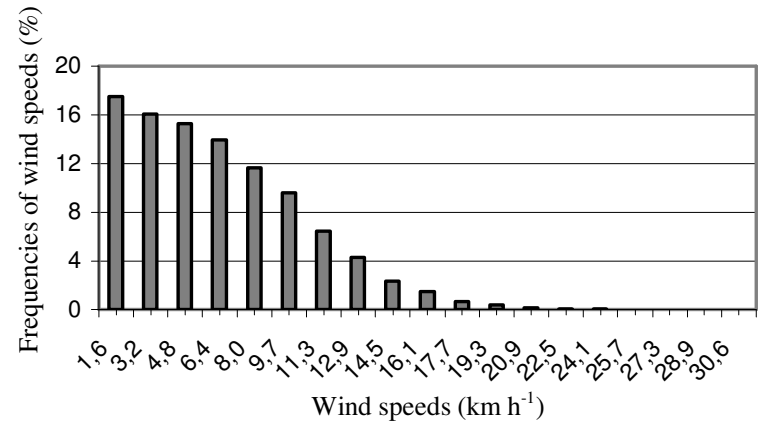

b)

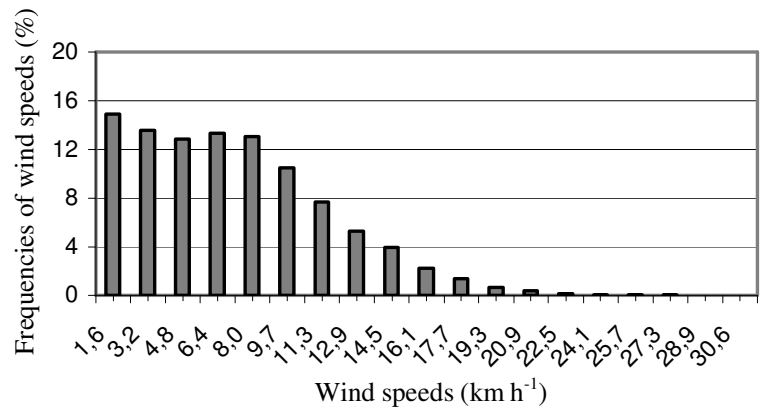

d)

Figure 3 - Wind frequencies (Y axis) for each of the wind speed step (X axis) supplied by the weather station at Point J. a) summer b)autumn c) winter and d) spring.

area and in order to provide a context for the current analysis an overall comparison of observed and reference data is presented. Both sites show that $\mathrm{N}$ and $\mathrm{NE}$ are important winds for all the seasons followed by S (Figure 2). E and SE become more relevant in warm seasons while SW in cold ones.

Wind speeds at Point $\mathrm{K}$ are about three times higher than those at Point $\mathrm{J}$ (Table 2); this result can be attributed to friction forces that decrease with height as was evidenced by the anemometers located at $10 \mathrm{~m}$ (Point $\mathrm{K}$ ) and $5 \mathrm{~m}$ (Point $\mathrm{J}$ ) above the ground. Differences due to terrain roughness and data quality must be taken into account as well. For instance, measurements based on hourly winds carried out at $12 \mathrm{~m}$ above the ground in a urbanized area near the industrial complex during four years (Ratto et al., 2006) showed a general average of $9.4 \mathrm{~km} \mathrm{~h}^{-1}$.

For the reasons explained above calms at Point $\mathrm{K}$ should be lower than those at Point $\mathrm{J}$ but calms at Point $\mathrm{K}$ are on average around $30 \%$ higher. This difference may be attributed to differences in data quality. Nevertheless note that both sites reveal the same trend (higher values in colder seasons than in warmer ones) being autumn the season with most of calm occurrences.

Table 3 is intended to show how wind frequencies depend on wind speeds. It provides an overview of wind frequencies regarding the wind ranges previously defined. Low wind speeds (below $6.4 \mathrm{~km} \mathrm{~h}^{-1}$ ) are more frequent in cold seasons (autumn and winter) than in warmer ones. On the other side, speeds above $8.0 \mathrm{~km} \mathrm{~h}^{-1}$ are more frequent in warmer than in colder seasons. Frequencies corresponding to speeds below $6.4 \mathrm{~km} \mathrm{~h}^{-1}$ (a very close value to those of any of the seasonal averages) represented $56.0 \%$ in summer, $62.8 \%$ in autumn, $59.5 \%$ in winter and $54.6 \%$ in spring (general average 58.2). Seasonal frequency wind roses for the five speed ranges showed strong correlation within the seasons (Figure 4). Note that major differences were observed for $\mathrm{N}$; the rest of the directions were very similar independently of the speed range.

As mentioned before the knowledge of wind patterns immediately after calms is important for air pollution modeling. While $S A D$ is a coefficient easy to compute, the computation of the $O O C$ wind roses as well as average wind roses for different speed ranges is a time-consuming task, then it is desirable to know the degree in which $O O C$ patterns can be "represented" by any of the particular range patterns. In this sense, $S A D$ provides the degree for the "error". According to this, wind roses that best represent the $O O C$ wind roses were that of the range 4.8- 6.4 for summer, that of the complete range for autumn, and that of the range 1.6- 3.2 for winter and spring (Table 4). Wind roses involving low wind speeds, i.e. range 1.6- $3.2 \mathrm{~km} \mathrm{~h}^{-1}$ and 4.8- 
Table 3 - Observed frequencies for different speed ranges corresponding to Point $\mathrm{J}$

\begin{tabular}{|c|c|c|c|c|}
\hline \multirow{2}{*}{$\begin{array}{c}\text { Wind speed range } \\
\left(\mathrm{km} \mathrm{h}^{-1}\right)\end{array}$} & \multicolumn{4}{|c|}{ Frequency (\%)a } \\
\cline { 2 - 5 } & Summer & Autumn & Winter & Spring \\
\hline $1,6-3,2$ & 28,7 & 33,6 & 32,9 & 28,4 \\
\hline $4,8-6,4$ & 27,3 & 29,2 & 26,6 & 26,2 \\
\hline $8-9,7$ & 25,1 & 21,3 & 22,1 & 23,6 \\
\hline $11,3-30,6$ & 18,9 & 15,9 & 18,3 & 21,9 \\
\hline Total & 100 & 100 & 100 & 100 \\
\hline
\end{tabular}

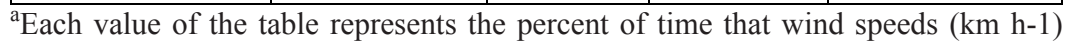
belonging to one particular range were occurring.

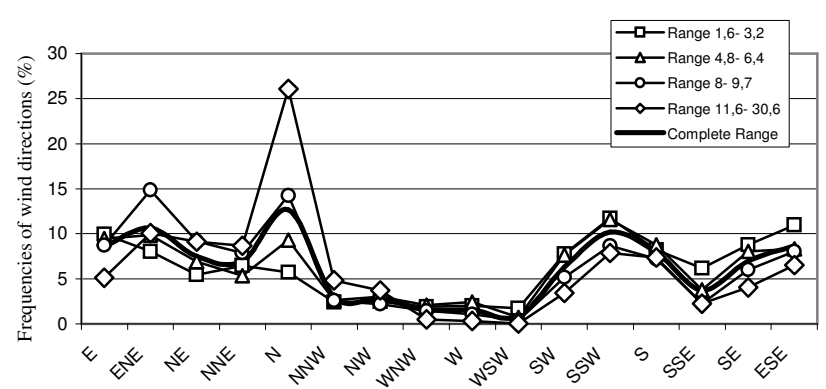

a)

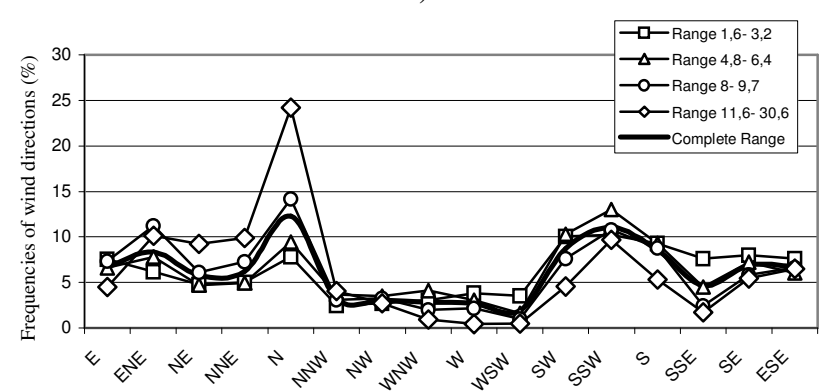

b)

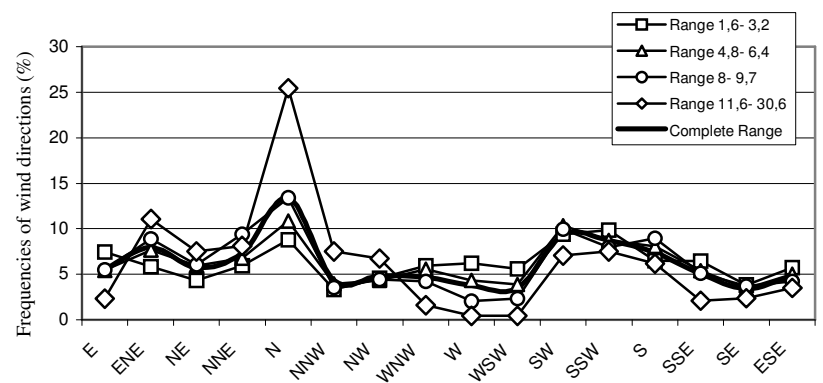

c)

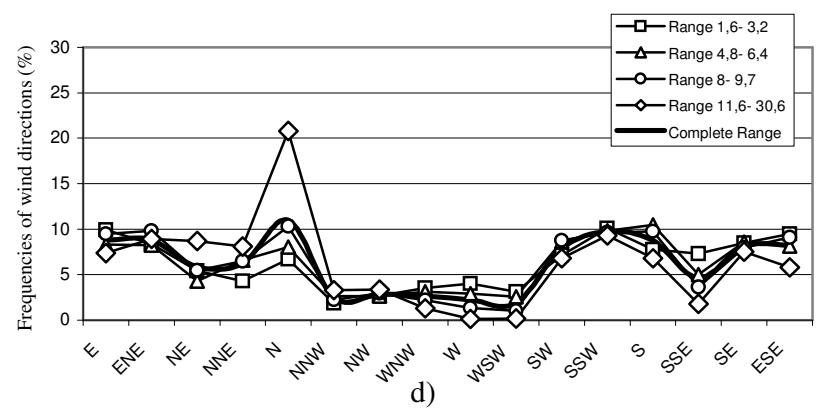

Figure 4 - Observed frequency wind roses at Point $\mathrm{J}$ according to different wind speed ranges. In boded line is represented the wind rose involving all wind speeds (complete range). a) summer b) autumn c) winter and d) spring.

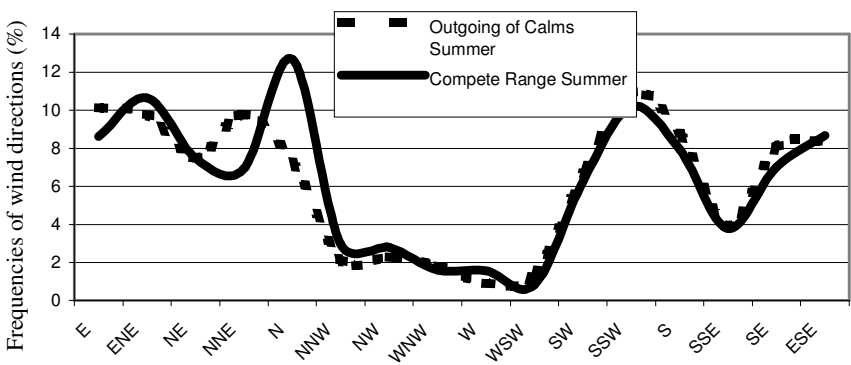

a)

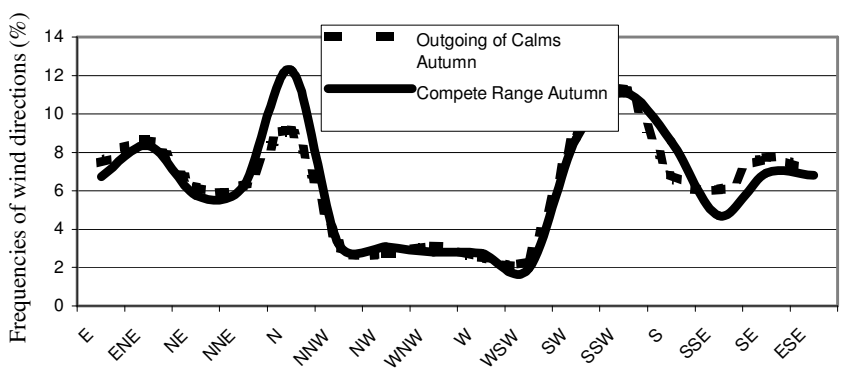

b)

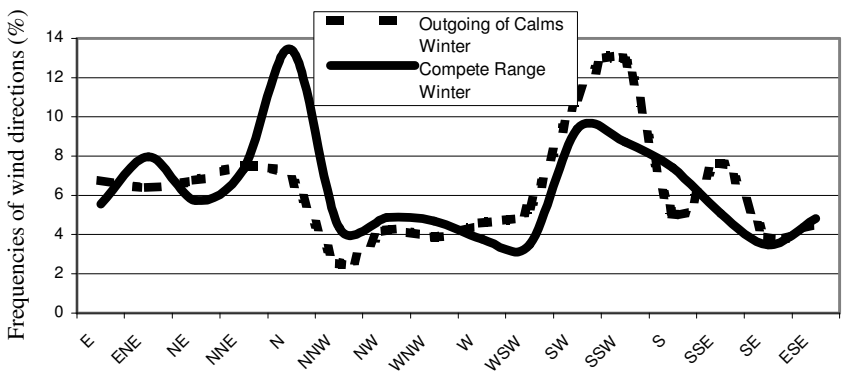

c)

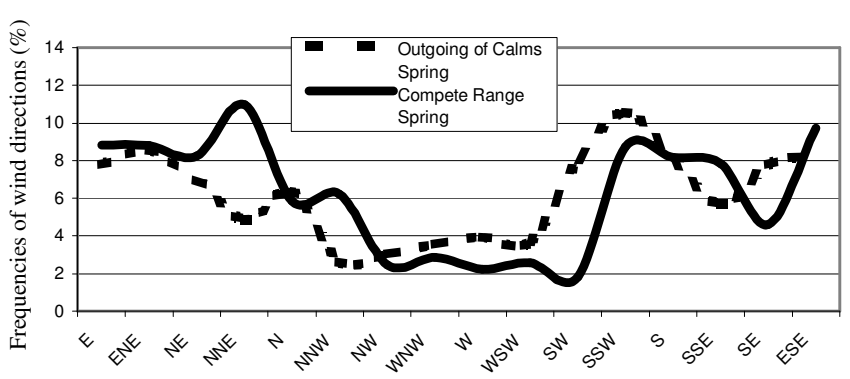

d)

Figure 5 - Outgoing of calms and complete range wind roses at Point J covering the period 1998- 2007. a) summer b) autumn c) winter d) spring. 
Table 4 - Frequencies (\%) for sectors 1 and 2 observed at Point J corresponding to the wind roses of Figure 5.

\begin{tabular}{|l|c|c|c|c|c|}
\hline & $\begin{array}{c}\text { Compete } \\
\text { Range } \\
1.6-30.6 \mathrm{~km} \mathrm{~h}^{-} \\
1\end{array}$ & $\begin{array}{c}\text { Range } \\
1.6-3.2 \mathrm{~km} \mathrm{~h}^{-1}\end{array}$ & $\begin{array}{c}\text { Range } \\
4.8-6.4 \mathrm{~km} \mathrm{~h}_{1}^{-} \\
1\end{array}$ & $\begin{array}{c}\text { Range } \\
8.0-9.7 \mathrm{~km} \mathrm{~h}_{1}^{-}\end{array}$ & $\begin{array}{c}\text { Range } \\
11.6-30.6 \mathrm{~km} \mathrm{~h}^{-} \\
1\end{array}$ \\
\hline Summer & 16,9 & 18,7 & 13,2 & 28,4 & 49,4 \\
\hline Autumn & 10,7 & 16,6 & 16,7 & 22,3 & 48,2 \\
\hline Winter & 27,9 & 20,7 & 24,1 & 69,0 & 66,4 \\
\hline Spring & 31,7 & 23,4 & 27,6 & 37,1 & 52,9 \\
\hline Average & $\mathbf{2 1 , 8}$ & $\mathbf{1 9 , 9}$ & $\mathbf{2 0 , 4}$ & $\mathbf{3 9 , 2}$ & $\mathbf{5 4 , 2}$ \\
\hline
\end{tabular}

Table 5 - Frequencies (\%) for sectors 1 and 2 observed at Point $\mathrm{J}$ corresponding to the wind roses of Figure 5.

\begin{tabular}{|c|c|c|}
\hline \multicolumn{3}{|c|}{ Sector 1 } \\
\hline & Outgoing of calm & Complete Range \\
\hline Summer & 26.8 & 30.1 \\
\hline Autumn & 24.8 & 27.5 \\
\hline Winter & 23.6 & 30.8 \\
\hline Spring & 20.9 & 25.5 \\
\hline \multicolumn{2}{|c|}{ Sector 2 } \\
\hline Summer & 28.4 & 27.9 \\
\hline Autumn & 23.1 & 21.9 \\
\hline Winter & 17.8 & 18.3 \\
\hline Spring & 24.7 & 25.9 \\
\hline
\end{tabular}

Frequencies (percent of occurrences of winds) for Sectors 1 and 2 involving all the seasons from the point of view of the OOC and the complete range wind roses

Table 6 - Ratio ${ }^{\text {a }}$ between wind speeds corresponding to complete range and outgoing of calm wind roses

\begin{tabular}{|c|c|c|c|}
\hline & All directions & Sector 1 & Sector 2 \\
\hline Summer & 2.5 & 2.5 & 2.3 \\
\hline Autumn & 2.6 & 2.6 & 2.7 \\
\hline Winter & 2.7 & 3.0 & 3.2 \\
\hline Spring & 2.3 & 2.7 & 2.7 \\
\hline Average & $\mathbf{2 . 5}$ & $\mathbf{2 . 8}$ & $\mathbf{2 . 6}$ \\
\hline
\end{tabular}

${ }^{\mathrm{a}}$ Ratio: average wind speed / outgoing of calms wind speed Column 2 indicates the ratio involving all directions of the compass, column 3 is the analogous but only for the directions of Sector 1, column 4 involves only the directions of Sector 2.

$6.4 \mathrm{~km} \mathrm{~h}^{-1}$ are on average more similar to the $O O C$ wind rose than wind roses involving the rest of the ranges including those of complete range. This result is according to what is expected because winds immediately after calms are likely to have low speeds., For the case under study, the $S A D$ allows infer that if the complete range wind rose is used instead of the $O O C$ wind rose the "error" is around $22 \%$.

Sectors 1 and 2 are of interest regarding air pollution control (Ratto et al., 2009). Sector 1 involves winds that carry air pollutants towards city center and Sector 2 involves winds that carry pollutants towards the main residential areas (Gonnet, City Bell, etc.).

Comparing observed frequencies between $\mathrm{OOC}$ and complete range wind roses for both sectors major differences appear in winter (maximal is 7.2\%) for Sector 1. For Sector 2 all the differences are below 1.2\% (Table 5). This implies that for these sectors the complete range wind rose predicts the outgoing of calms wind rose with a small error.

For all the directions of the compass but particularly for sectors 1 and 2 it is important to estimate the relationship between wind speeds regarding complete range and $O O C$ wind roses. In most cases, wind speeds involving both sectors are around 2.5-3 times lower than those of the average wind speeds (Table 6).

As mentioned before (Section 1) pollutants tend to accumulate during calm events but also large pollutant concentrations might occur under convective low wind conditions due to elevated point sources (Moore, 1969; Deadorff, 1984) such as those belonging to the petroleum processing plants. According to McCormick (1968), the persistence of surface wind less than $10 \mathrm{~km} \mathrm{~h}^{-1}$ is usually conductive to the accumulation of air pollutants. Sharan et al. (1996) and Goyal and Rama Krishna (2002) say that surface winds below $7.2 \mathrm{~km}$ $\mathrm{h}^{-1}$ at $10 \mathrm{~m}$ level are considered as low wind speeds.

Applying to the well- known potential formulae to correct wind speed exposures (Seinfield and Pandis, 2006) and considering site $\mathrm{J}$ as a rural place and neutral stability (see Section 2.1), the corrected value for $6.4 \mathrm{~km} \mathrm{~h}^{-1}$ corresponds to $7.1 \mathrm{~km} \mathrm{~h}^{-1}$. So considering the information given in Table 3 (see frequencies for wind speeds $\leq 6.4$ and $\leq 9.7 \mathrm{~km} \mathrm{~h}^{-1}$ ), Table 2 and the average predominant role of the stability classes D and E (Mazzeo et al., 1971) most of the time the area has conditions that make difficult the removal of airborne pollutants. Regarding smoke plumes during winter nights -when stability class E together with low mixing heights (see Section 2.1) are more probable to occur- smoke plumes with "fanning" characteristics may develop (Stull, 1988) making difficult the vertical dispersion of air pollutants.

Knowledge on how frequent low wind speeds may occur in the area should be taken into account when applying Gaussian plume dispersion type models because (for low wind speeds) such models increase the error in the prediction of air quality pollutant concentrations as far as wind speeds decrease (Goyal and Rama Krishna, 2002).

Updated long fieldworks involving boundary layer regimes during daytime such as the Ulke and Mazzeo (1998) 
analysis for Buenos Aires City and the approaches suggested by Mahrt (1979) and Mahrt et al. (1998) for nighttime involving wind profiles, mixing heights and stability analyses as well as land- sea breeze studies (Tayt-Son et al., 2010) involving land- sea breeze front variations with time (Simpson, 2006) are of vital importance in order to deepen in the physical aspects of pollutant transport and finally to reinforce or correct the preliminary findings of this work.

Regarding pollution control, a medium term campaign assessing basic meteorological parameters -such as wind direction frequencies, wind speeds, calms, minimum temperature, pressure and relative humidity- (Lalas et al., 1982) together with some primary industrial and power plant air pollutants (such as $\mathrm{SO}_{2}, \mathrm{PM}_{10}, \mathrm{NOx}$ ) will be very adequate to settle reference for the air pollution status of La Plata area.

\section{CONCLUSIONS}

The study focuses on local observations but other scales (involving regional low- level jets and El Niño phenomena) should be considered in the future to provide an integrated and realistic overview of local processes.

Observed seasonal wind frequency patterns for the period under study were found very similar to those corresponding to La Plata Airport taken as reference. Wind speeds and calms did not keep such similarity but the differences can be explained in terms of exposure, terrain roughness and data quality.

Frequency wind roses for different speed ranges exhibited a very similar pattern. North direction showed major variations; it increases its frequency as far as averaged wind speed does.

Knowledge of winds after calms is very important in order to gain insight in wind characteristics. Wind direction frequencies considering only wind speeds during the first hour after calms showed a very similar pattern to that of the complete speed range frequency pattern; for the case under study, the first can be predicted by the latter with a small error.

Wind speeds after calms involving sectors 1 and 2 are significantly lower than their corresponding general averages for these sectors. This implies that not only calm events are of concern for the accumulation of air pollutants but also low wind speeds.

La Plata city area needs long systematic fieldworks regarding meteorological aspects of air pollution transport, modeling and assessment. This will enrich the main findings of this preliminary study.

\section{ACKNOWLEDGMENTS}

The authors are grateful to the Experimental Station "Julio Hirschhorn" of La Plata National University for providing the data at Point J and to Dr. Christian Weber for his help. Our particular thanks to Drs. Jorge Reyna Almandos and Fabián Videla for their contributions to this paper. We also appreciate very much the help of Dr. Alberto Lencina from CIOp.

\section{REFERENCES}

ALVÁREZ ESCUDERO, L.; ALVÁREZ MORALES, R.; ROQUE RODRIGUEZ, A. Climatología del Viento y sus Aplicaciones II, 2007. Aplicaciones. En: Contribución a la Educación y la Protección Ambiental. Cátedra de Medioambiente. Instituto Superior de Ciencias y Tecnologías Nucleares. p.5 Editorial Academia, La Habana, Cuba.

BERRI G.J.; SRAIBMAN, L.; TANCO, R.; BERTOSSA, G. Low-level wind field climatology over the La Plata River region obtained with a mesoscale atmospheric boundary layer model forced with local weather observations. Journal of Applied Meteorology and Climatology, 49, 6, 1293 1305,2010

CATALDI, M.; FREITAS ASAD, L. P.; TORRES JUNIOR, A. R.; DRUMMOND ALVES, J. L. Estudo da influência das anomalias da tsm do atlântico sul extratropical na região da confluência brasil malvinas no regime hidrometeorológico de verão do sul e sudeste do Brasil. Revista Brasileira de Micrometeorologia 25: 513- 524, 2010.

COLOMBO, J. C.; LANDONI, P.; BILOS, C. Sources, distribution and variability of airborne particles and hydrocarbons in La Plata area, Argentina. Environmental Pollution, 104: 305- 314, 1999.

CONRAD, V.; POLLAK, L. W.. Methods in climatology, $2^{\text {nd }}$ Edition. 459 pp. Harvard university press, Cambridge, Massachusetts, 1950.

DEARDORFF, J.W. Upstream diffusion in the convective boundary layer with weak or zero mean wind. In: FOURTH JOINT CONFERENCE ON APPLICATION OF AIR POLLUTION METEOROLOGY, 1984. American Meteorological Society, Boston Massachusetts. Anais... 1984.

GOYAL, P.; RAMA KRISHNA, T.V.B.P.S. Dispersion of pollutants in convective low wind: a case study of Delhi. Atmospheric Environment, 36 2071-2079, 2002.

HOLZWORTH, G.C., 1967 Mixing depths, wind speeds and air pollution potential for selected locations in the United States. Journal of Applied Meteorology, 6: 1039- 1044

LALAS, D.P.; VEIRS, V.R.; KARRAS, G.; KALLOS, G. An analysis of the $\mathrm{SO}_{2}$ concentration levels in Athens, Greece. Atmospheric Environment, 16: 531-544, 1982.

MAHRT, L. An Observational Study of the Structure of the nocturnal boundary layer. Boundary Layer Meteorology, 17: 247-264, 1979. 
MAHRT, L.; SUN, J.; BLUMEN, W.; DELANY, T.; ONCLEY, S. Nocturnal boundary layer regimes. Boundary Layer Meteorology, 88:255-278, 1998.

MARAÑON DI LEO, J.; DEL NERO, S.; RAGAINI, J. C.; SACCHETTO, V.; COLOSQUI, J.; COLMAN, J.; BOLDES, U.; SCARABINO, A.; ROSATO, M.; REYNA ALMANDOS, J. Air Concentrations of $\mathrm{SO}_{2}$ and Wind Turbulence near La Plata Petrochemical Pole (Argentina). Latin American Applied Research, 34: 55- 58, 2004.

MASSOLO, L.; MÜLLER, A.; TUEROS, M.; REHWAGEN, M.; FRANK, U.; RONCO, A.; HERBARTH, O. Assessment of Mutagenicity and Toxicity of Different-Size Fractions of Air particulates from La Plata, Argentina, and Leipzig, Germany. Environmental Toxicology, 17: 219- 231, 2002.

MASSOLO L.; REHWAGEN, M.; PORTA, A.; RONCO, A.; HERBARTH, O.; MUELLER, A. Indoor-outdoor distribution and risk assessment of volatile organic compounds in the atmosphere of industrial and urban areas. Environmental Toxicology, 25: 339-349, 2010.

MAZZEO, N.; NICOLINI, M.; MOLEDO, L.; MICHELONI, R. Condiciones de Estabilidad Atmosférica y Capacidad de Dilución Vertical de Contaminantes en la Ciudad de La Plata. AIDIS, Buenos Aires pp. 101- 114, 1971.

MCCORMICK, R. A. Air Pollution Climatology. In: Air Pollution (Stern, A.) Vol. 1 Chapter 9 Second Edition New York Academic Press, New York, 1968.

MOORE, D.J. The distributions of surface concentrations of sulphur dioxide emitted from tall chimneys. Transactions of the Royal Society, 265, 1969.

NEGRIN, M.; DEL PANNO, T.; RONCO, A. Study of bioaerosols and site influence in the La Plata area (Argentina) using conventional and DNA (fingerprint) based methods Aerobiologia, 23:249-258, 2007.

NITIU, D.S. Aeropalynologic analysis of La Plata City (Argentina) during 3-year period. Aerobiologia, 22: 7987, 2006.

PETCHENESHKY, T.; GRAVAROTTO, M.C.; BENITEZ, R.; DE TITTO, E. Gestión de la Calidad de Aire UrbanoIndustrial. Situación del Monitoreo de la Calidad del Aire (GEMS- AIRE) en la República Argentina. pp. 1- 12 Departamento de Salud Ambiental del Ministerio de Salud y Acción Social de La Nación, AIDIS, Buenos Aires, 1998.

RATTO, G.; VIDELA, F.; REYNA ALMANDOS, J.; MARONNA, R.; SCHINCA, D. Study of meteorological aspects and urban concentration of $\mathrm{SO}_{2}$ in atmospheric environment of La Plata, Argentina. Environmental Monitoring and Assessment, 121: 327- 342, 2006.

RATTO, G.; VIDELA, F.; MARONNA, R. Analyzing $\mathrm{SO}_{2}$ concentrations and wind directions during a short monitoring campaign at a site far from the industrial pole of La Plata,
Argentina. Environmental Monitoring and Assessment, 149: 229- 240, 2009.

RATTO, G.; VIDELA, F.; MARONNA, R.; FLORES, A.; DE PABLO, F. Air pollutant transport analysis based on hourly winds in the city of La Plata and surroundings, Argentina. Water, Air \& Soil Pollution, 208: 243- 257, 2010a.

RATTO, G.; MARONNA, R.; BERRI, G. Analysis of wind roses using hierarchical cluster and multidimensional scaling analysis at La Plata, Argentina. Boundary Layer Meteorology, 137: 477- 492, 2010b.

REHWAGEN, M.; MÜLLER, A.; MASSOLO L.; HERBARTH, $\mathrm{O}$; RONCO, A. Polycyclic aromatic hydrocarbons associated with particles in ambient air from urban and industrial areas. Science of the Total Environment, 348: 199-210, 2005. RONCO, A.; MÜLLER, A.; REHWAGEN, M.; MASSOLO, L.; TUEROS, M.; PORTA, A.; FRANCK, U.; HERBARTH, O. Influence of industrial, traffic and domestic emissions in the air quality of La Plata (Argentina) and Leipzig (Germany) and the potential risk associated with respiratory diseases and allergies, 2001 Proceedings of II Mercosul Chemical Industry Congress and VII Brazilian Petrochemical Congress, IBP 13001. Anais... Rio de Janeiro: IBPBrazilian Petroleum and Gas Institute, 2001.

ROSATO, M. E.; REYNA ALMANDOS, J.; RATTO, G.; FLORES, A.; SACCHETTO, V.: ROSATO, V. G.; RIPOLI, J.; ALBERINO, J. C.; RAGAINI, J. C. Mesure de $\mathrm{SO}_{2}$ à La Plata, Argentine. Pollution Atmosphérique 169: 85- 98, 2001.

SEINFELD, J.H.; PANDIS, S.N. Atmospheric Chemistry and Physics. From Air Pollution to Climate Change. Second Edition, John Wiley \& Sons, New Jersey, 2006.

SHARAN, M.; KUMAR YADAV, A.; SINGH, M.P.; AGARWAL, P.; NIGAM, S. A mathematical model for the dispersion of air pollutants in low wind conditions. Atmospheric Environment, 30: 1209- 1220, 1996.

SIMPSON, J.E. Sea breeze and local wind. Cambridge University Press, Cambridge, UK, 2006.

SRAIBMAN, L.; BERRI G.J. Low-level wind forecast over the La Plata River region with a mesoscale boundary layer model forced by regional operational forecasts Boundary Layer Meteorology, 130:407- 422, 2009.

STULL, R.B. An introduction to Boundary Layer Meteorology. Dordrecht: Kluwer Academic Press, The Netherlands, 1988.

TAYT-SOHN, F.C.O.; OLIVEIRA MORAES, N.; MARTON, E.; GOMES PIMENTEL, L.C. Estudo da Influencia dos Efeitos da Brisa Marítima Sobre a Ilha de Calor Urbana na Região Metropolitana do Rio de Janeiro Utilizando o Modelo MM5. XVI CONGRESSO BRASILEIRO DE METEOROLOGIA 13 a 17 de Setembro, 2010. Anais... 
Belem, Brazil Disponível em http://www.cbmet2010.com/ anais/artigos/477_19535.pdf. 2010.

ULKE, A. G. Aerosol characterization in Buenos Aires and relationships with transport patterns in South America. Revista Brasileira de Micrometeorologia. Edição especial, 2009.

ULKE, A.; MAZZEO, N. Climatological aspects of the daytime mixing height in Buenos Aires City, Argentina. Atmospheric Environment, 32:1615- 1622, 1998.

ULKE, A.G.; LONGO, K.M.; FREITAS, S. R.; HIERRO, R.F. Regional pollution due to biomass burning in South America. Ciếncia e Natura 10, 201, 2007.
WHICHMANN, F.A.; MÜLLER, A.; BUSI, L.E.; CIANNI, N.; MASSOLO, L.; SCHLINK, U.; PORTA, A.; SLY, P.D. Increased asthma and respiratory symptoms in children exposed to petrochemical pollution. Journal of Allergy and Clinical Immunology, 123: 632- 638, 2009.

WIERINGA, J. Does representative wind information exist? Journal of Wind Engineering \& Industrial Aerodynamics, 65: 1- 12, 1996.

WIERINGA, J. Representativeness of Wind Observations at Airports, Bulletin of the American Meteorological Society, 61: 962- 971, 1980. 